\title{
The Biology of Balanus balanoides. III. The Soft Parts.
}

\author{
By \\ Hilary B. Moore, Ph.D., \\ Marine Biological Laboratory, Plymouth.
}

With 4 Figures in the Text.

\section{Contents.}

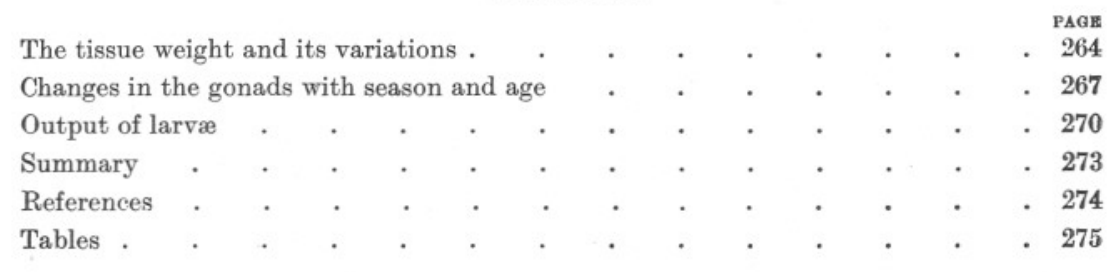

In the first paper of this series an account was given of the growth of this species, and its variation with age, season and tidal level. The size of the barnacles was expressed in terms of the external volume of the shell, as determined from measurements of its length, breadth and height, usingthe formula Vol. $=0.065$ Ht. $\times(\text { Length }+ \text { Breadth })^{2}$, (Moore, 1934, p. 852). So far as the shell was concerned, there was a period of rapid growth during the summer, followed by a period of little or no growth during the winter months. The first part of the present paper comprises an account of the corresponding changes in the soft parts of the barnacles.

Runnström (1925) states that the spat which settle in the early summer, grow very rapidly during their first summer, and do not develop more than rudimentary gonads until their second autumn. Because of the existence of this vegetative year, and because thereafter the gonads (and later, the larvæ in the mantle cavity) form a considerable proportion of the bulk of the tissues a distinction had been made throughout the work between immature first-year animals and those of two or more years old which are sexually mature. Actually it was found that in some special cases the vegetative first year was omitted. The distinction between first-year and older barnacles was made by means of differences in their colour as has been described in another paper (Parke and Moore, 1935). Most of the material was collected in Port Erin Bay in the locality previously used (Moore, 1934, p. 852). It was taken from three levels, B.1 just below mean sea level and representing the lower-zone type of barnacles for this locality ; 
B.2 between this and mean high water of neap tides, and representing the principal barnacle zone of the shore; and B.3 slightly above mean high water of neap tides and representing the type of barnacles found at their extreme upper limit. Additional patches B.4 and B.5 at the same levels as B.1 and B.2 respectively comprised barnacles of a known age only, all others having been removed from the rock. Finally two sets of samples were taken at successive levels outside Bradda Head in a very exposed situation.

\section{The Tissue Weight and its Variations with Age, Season and Tidal Level.}

Barnacles were removed from the rocks, to which they were attached, with the aid of a knife, care being taken to remove the whole of the animal, and at the same time not to take any adhering fragments of rock. The material was then taken back to the laboratory where it was sorted according to its size, each size-group containing an adequate amount of barnacles for weighing. The number in each group varied from five to fifty according to their size. Either the whole or a part of each group was measured (length, breadth and height), and the whole group was then transferred to boiling water for a minute in order to coagulate the proteins and reduce loss of material in subsequent treatment. The barnacles were then decalcified in cold hydrochloric acid (one part in five), washed and transferred to a tared filter paper, then dried in a boiling-water oven and weighed. The resulting mean weight and volume for each group, as obtained in the successive seasonal samples, are given in Table I to V.

In Figure 1 is shown the normal growth of the shell at the three levels in Port Erin Bay (Moore, 1934, p. 858), and the corresponding growth of the tissues as obtained from these tables. The resulting curves are very complicated, and the possible explanations given are no more than tentative. The curve for the lowest level patch, B.1 is the simplest. The body weight rises fairly steadily up to the first spring. About July the weight begins to drop, reaching a minimum in August, after which it rises steadily again until the following spring, if the animal lives so long. In the case of these low-water barnacles, spawning takes place in the first season, the ova being liberated into the mantle cavity about mid-November, and the larvæ liberated into the sea in March. The average number of nauplii produced by a B.1 barnacle in its first year is 360 (see p. 270), and their weight, $0.27 \mathrm{mgm}$., is negligible in relation to the total weight of the barnacle. The drop of $50 \%$ in weight is connected with spawn production, but it also corresponds with the period of maximum sea temperature which occurs in mid-August.

At the middle and upper level, B.2 and B.3, no spawning takes place 


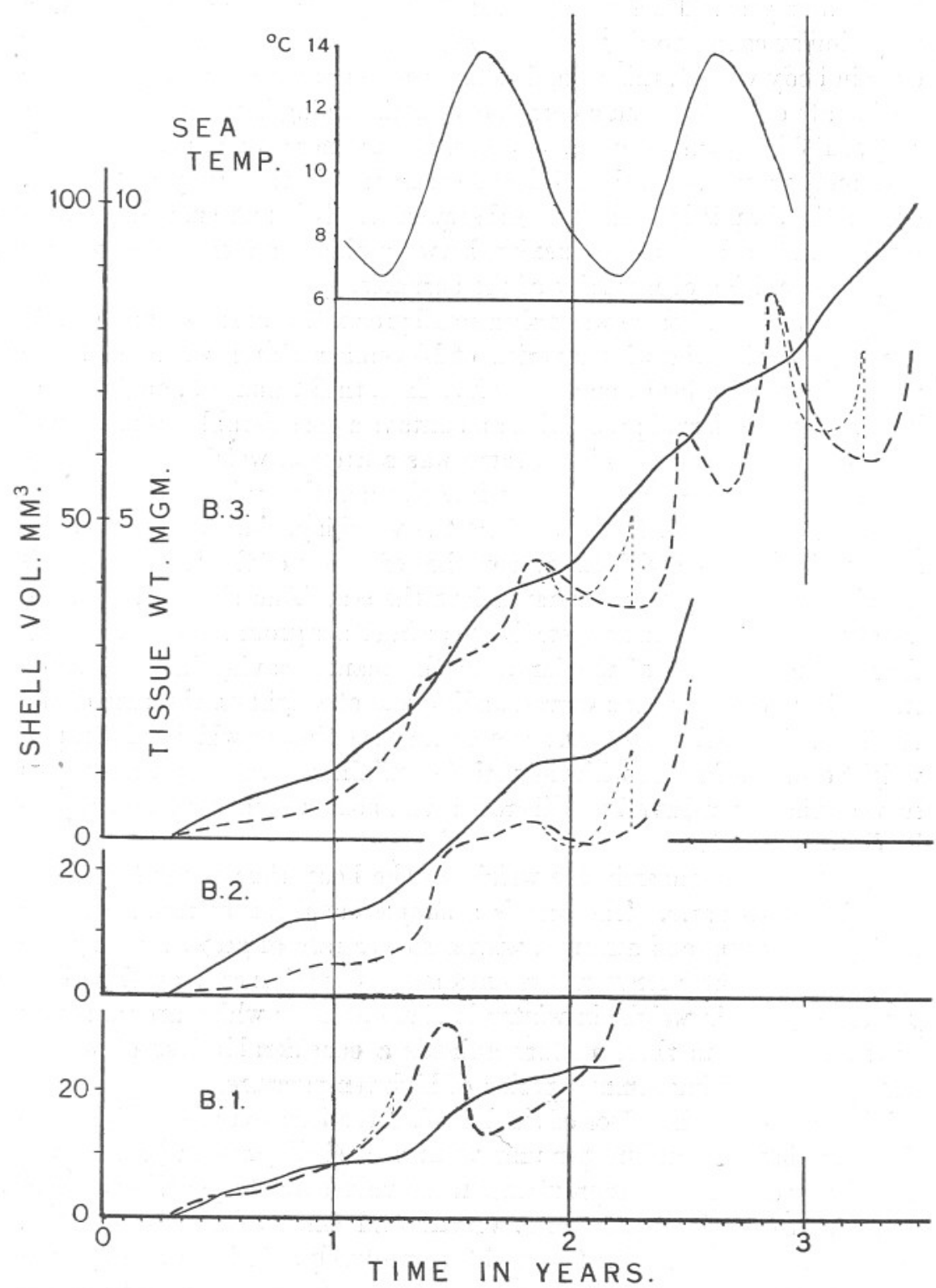

FIG. 1.-Growth of typical B. balanoides at Port Erin at low- (B.1.), intermediate- (B.2) and high-level (B.3), in terms of external shell volume (whole line) and dry weight of decalcified tissues (broken line). The lighter broken line indicates the weight values over the period when there were larvæ in the mantle cavity, as inferred from the known spawn output, but not shown in the main curve owing to wide spacing of readings at that period. The mean sea surface temperatures for Port Erin Bay are shown above. 
in the first year. During this vegetative period body growth follows a very similar course to that on B.1, except that there is no actual summer drop in body weight, this being indicated merely by a temporary decrease in the rate of growth, and a corresponding flattening in the curve. In the case of B.3 in its third season, however, the summer drop in body weight is extremely pronounced, though less so than that in the first year on B. 1, and as the drop is in both cases subsequent to their first spawning, there would seem to be some connexion between this summer loss of weight and the condition of maturity of the barnacle.

In the case of B.1 there was only a small production of spawn and no loss of weight during the winter period of November-March when the larvæ were being carried in the mantle cavity. In both B.2 and B.3, on the other hand, where the larval production amounts to a considerable proportion of the total weight of the animal, there was a drop in weight immediately following the liberation of the ova into the mantle cavity. This drop is not due to the loss of the larvæ from the weighing, since they continued to be weighed along with the rest of the soft parts of the barnacles until the time when they were liberated into the sea. And since such a drop is not present in the first vegetative year in either group, it would appear that the maturation of the larvæ in the mantle cavity involves some expenditure of energy and corresponding loss of weight on the part of the barnacle. It should, however, be noted that the time at which this drop in weight occurs coincides with the period of minimum sea temperature. As soon as the larvæ have been liberated, the body weight rises steadily to its June maximum.

The cycle of changes in the weight of the body thus seems to resolve itself into two parts. The first is a simple condition of rapid increase during the spring and autumn, with a slower rate of growth during the summer and winter temperature extremes. Superimposed on this there is a slight drop in weight in winter in those animals which are maturing larvæ, and also in these mature animals a considerable loss of weight during the following summer period of high temperature.

With regard to the effect of tidal level, those barnacles from higher up the shore have less tissue per unit volume of shell (external) than those from lower down. The approximate mean values for the year, in terms of mgm. of dried tissue per $\mathrm{mm}^{3}$. of external shell volume were $0 \cdot 130$, 0.083 and 0.080 on B.1, B.2 and B. 3 respectively. It is to be expected that the barnacles most exposed to dessication from solar radiation, will require the thickest shells for protection. This has already been shown in the case of limpets (Orton, 1933). 


\section{Changes in the Gonads with Season and Age.}

The general anatomy of the barnacle has been described by Darwin (1851), Gruvel (1905), Krüger (1927) and others. Spence-Bate (1869) has described the process of impregnation, and Hoek (1876) and Runnström (1925) describe the larval stages and process of metamorphosis. The larvæ are normally liberated into the sea as Stage I nauplii, although Runnström records a doubtful case where they may perhaps have been retained and not liberated until the cypris stage.

According to Runnström the barnacles at Herdla near Bergen begin to ripen their ova at the end of October or beginning of November. The embryos develop in the mantle cavity during the winter and are liberated in maximum numbers about the middle of March. At the end of March and beginning of April they begin to settle as Cypris on the shore. Elmhirst (1922), describing conditions at Millport in the Clyde, gives the hatching season as January to April, with a maximum in March and April. Johnstone, Scott and Chadwick (1924), summarising fourteen years' plankton investigations in Port Erin Bay, show that a few Balanus nauplii are present throughout the year, but that the greatest numbers occur from February to April.* There is an interval between the maxima for the nauplius and the cypris stages of nearly two months, and where the nauplii were taken in ten thousands, the cypris were taken only in tens. The difference was no doubt due in part to mortality and to dispersal of the larvæ, and in part also to the difference in time of duration of the two stages. The monthly mean figures given by them are shown below. $\dagger$

\begin{tabular}{|c|c|c|c|c|c|}
\hline \multicolumn{2}{|l|}{ Month. } & & & Nauplii. & Cypris \\
\hline December & . & . & . & 2 & - \\
\hline January & . & . & . & 404 & - \\
\hline February & . & . & . & 5322 & - \\
\hline March . & . & . & . & 35224 & - \\
\hline April . & . & . & . & 11021 & 40 \\
\hline May & . & . & . & 585 & 70 \\
\hline June . & . & . & . & 13 & 5 \\
\hline July . & • & . & $\cdot$ & - & - \\
\hline August & . & . & . & 1 & - \\
\hline
\end{tabular}

In 1932 we observed the first settled cypris larvæ on the rocks at Port Erin on April 26th, in 1933 on April 25th, and in 1934 on the same date. This shows surprisingly little variation in successive years. Hatton and

\footnotetext{
* The species was not identified, but B. balanoides is far the most abundant species in the neighbourhood.

$\dagger$ These are the mean numbers for the half of the combined hauls of a No. 19 and a No. 20 gauge net, $35 \mathrm{~cm}$. in diameter, towed for a distance of 800 metres.
} 
Fischer-Piette (1932) record the first settled spat near St. Malo in 1930 between March 29th and April 2nd, the subsequent settlement continuing for about six weeks. In 1931 the first spat settled between February 15th and March 4th, and the settlement lasted for about three months. Grave (1933) gives the date of metamorphosis at Woods Hole, Massachusetts, as February 15th to March 15th.

The material used in the present work on the condition of the gonads was collected at intervals throughout the year from the three levels at Port Erin, and also from the two extra patches of barnacles of known age, B.4 and B.5. From three to ten individuals of each recognisable yeargroup, from each level, were decalcified and sectioned, and the following is a summary of the results obtained.

\section{B.1 (and B.4). Low level.}

March 17th, 1933.

All barnacles contained advanced larvæ in the mantle cavity.

April 28th, 1933.

Spawning of larvæ entirely over. Large specimens contained developing ova and a medium-sized ovary. Even some first-year barnacles showed ova. No proliferation of testicular cæcæ.

June 26th, 1933.

No proliferation of testicular сæсæ in any specimens. Firstyear specimens with small ova and ovaries. Older barnacles with larger ova and ovaries.

September 18th, 1933.

First-year barnacles with small testicular cæcæ containing early spermatogenesis stages. Ovaries small, with small developing ova.

Older individuals with large testicular cæcæ, and more advanced sperm, some apparently ripe. No spermatozoa yet in vesiculæ seminales. Ovaries as in first-year specimens, but larger and more mature.

November 1st, 1933.

Ovaries of all ages full of large ova. Abundant sperm in both testicular сæсæ and vesiculæ seminales, though spermatogenesis stages still present in the former.
B.2 (and B.5). Intermediate level.

All but the first-year specimens contained advanced larvæ in the mantle cavity. Firstyear specimens showed no gonad development.

Conditions similar to B.1, except for the absence of developing gonads in first-year individuals.

First-year barnacles with no trace of gonads. Older ones as on B.1.
First - year specimens showed no gonad development. Older ones had mantle cavities containing large numbers of advanced larvæ, except some senile individuals (see p. 270). B.2.

Conditions as on B.2.

Conditions as on B.2.

First-year barnacles with no trace of gonads. Older ones as on B.1.
Conditions similar to
First-year individuals with no gonads. Older specimens as on B.1.
Conditions as on B.2, but a few individuals had shed their ova into the mantle cavity where they had been fertilised. Some senile specimens with few or no ova in the ovary. 
Two sets of samples also were collected from the more wave-exposed locality outside Bradda Head, and the following is a summary of the results obtained from them.

September 5th, 1933.

Level $-5^{\prime} 5^{\prime \prime}$ (slightly above low water of ordinary neap tides).

First-year individuals with no proliferation of the testicular cæcæ, but the vesiculæ seminales were large. Ovaries containing small developing ova.

Second-year and older individuals with slight proliferation of the testicular cæcæ and early spermatogenesis stages, but no ripe sperm. Ovaries larger and more mature than in the younger specimens.

Level-1' $1^{\prime \prime}$ (slightly below mean sea level).

First-year specimens with no trace of gonads. Older ones with large testicular cæcæ containing some apparently mature sperm. Ovaries large and containing large ova.

Level. $+6^{\prime} 2^{\prime \prime}$ (high water of ordinary neap tides).

Conditions as at $-1^{\prime} 2^{\prime \prime}$, except that no mature sperm were seen.

Level. $+7^{\prime} 2^{\prime \prime}$.

Conditions as at a foot lower.

November 17th, 1933.

Level. $-5^{\prime} 5^{\prime \prime}$.

Gonads ripe in all ages. Vesiculæ seminales full or ripe sperm. Ovaries smaller in first year than in older specimens, but in both cases full of mature ova. At this level no specimens were found which had shed their ova.

Level. $+7^{\prime} 6^{\prime \prime}$.

All mature individuals (more than one year old) had shed their genital products and contained early developing embryos, except certain senile individuals, of which there was a large proportion among the biggest specimens.

These results may be summarised as follows. At all levels the ovaries develop and mature considerably earlier than the testes, and are in fact well developed while the barnacle is still carrying in its mantle cavity the larvæ of the previous brood. The testicular cæcæ begin to proliferate and show early spermatogenesis stages in the autumn, and ripe spermatozoa are to be found by November. In this month shedding of the ova and impregnation take place, the barnacles from the highest level on the shore being most advanced, and shedding their genital products first. Liberation of the nauplii into the sea takes place from February onwards, with a maximum in March, the liberation also commencing slightly earlier in those animals which are furthest up the shore.

At these localities (Port Erin and Bradda) the first-year barnacles do not develop gonads at levels on the shore above about half-tide level. Below this point maturation occurs in the first year, and development follows much the same course as it does in the second year at higher levels, except for being slightly slower in the earlier stages. The age of maturity was checked on the patches B.4 and B.5 at Port Erin. On B.5 $(+2.74$ feet O.D.) which was completely scraped early in 1932 in time to receive the spat-fall of that year, no larvæ were found in any of the 1932 brood when these were examined in the spring of 1933 . On B.4 on the other hand ( $-0 \cdot 75$ feet O.D.), which was cleared at the same time, all individuals showed larvæ in the mantle cavity the following spring. 
Runnström records that at Herdla the majority of the first-year barnacles were without gonads, but that a few small individuals, apparently in their first year, were found to contain nauplii. He does not state the level at which these were taken, but it looks as though they were comparable with the early-maturing B.1 type at Port Erin.

In the above account of the conditions of the gonads, some individuals are recorded as senile. The cause of this condition is not known. Such individuals have been found only in the extreme upper limit of the barnacle zone (B.3). The condition is not limited to isolated barnacles, being equally common in members of crowded communities. It is found chiefly in the larger individuals, becoming more frequent with increasing size, and was never seen in very small specimens. In fact it appears to be a condition which is subsequent on at least one season of normal spawning, as distinct from a type of permanent sterility which will be described in a later paper. Progressive stages in the onset of this senility may be found (Fig. 2), from those barnacles which produce a normal number of larvæ, through those which produce a few only, to those which produce none at all. In the latter the appearance of the ovary when the animal is removed from the rock, is large and swollen, and yellow in colour and quite distinct from the normal condition. In section, those with a small larval content are apparently normal, except that in some cases they seem to contain an abnormally high proportion of relict ova. Some of those individuals which have failed to produce any larvæ at all, are found to have produced both ova and sperm, but have failed to shed either. In more extreme cases the ovary is reduced in size, and seems to have produced few or no ova, and in some of these the amount of sperm in the vesiculæ seminales is also less than normal. Finally, in one of the most pronounced examples examined the testicular cæcæ were in a very retarded condition and contained only early spermatogenesis stages at a time when they should have been filled with ripe spermatozoa.

The reason for this sterility is not apparent. It may possibly be due to some form of parasitic castration, since many barnacles are found to contain one or more unidentified cysts about $200 \mu$ in diameter. Lebour (1911) has recorded Cercaria balani encysted in this species, and Gregarina cysts are also known in various barnacles (Trégouboff, 1912; Kamm, 1922). In addition an Epicarid Isopod, Hemioniscus balani (Sp. Bate) is known to infect Balanus balanoides in some localities, but only a single specimen was found in the whole of the work at Port Erin.

\section{OUtPut of LaRve.}

For the determination of the larval output, material was collected in February, 1933, from the three levels at Port Erin at a time when the 
larvæ were well developed, but when no spawning had taken place. A series of specimens was chosen, covering the full range of sizes at each level, and the size (length, breadth and height) of each individual was measured. The mass of larvæ was then removed from the mantle cavity of each, and teased apart under a dissecting microscope, and either the

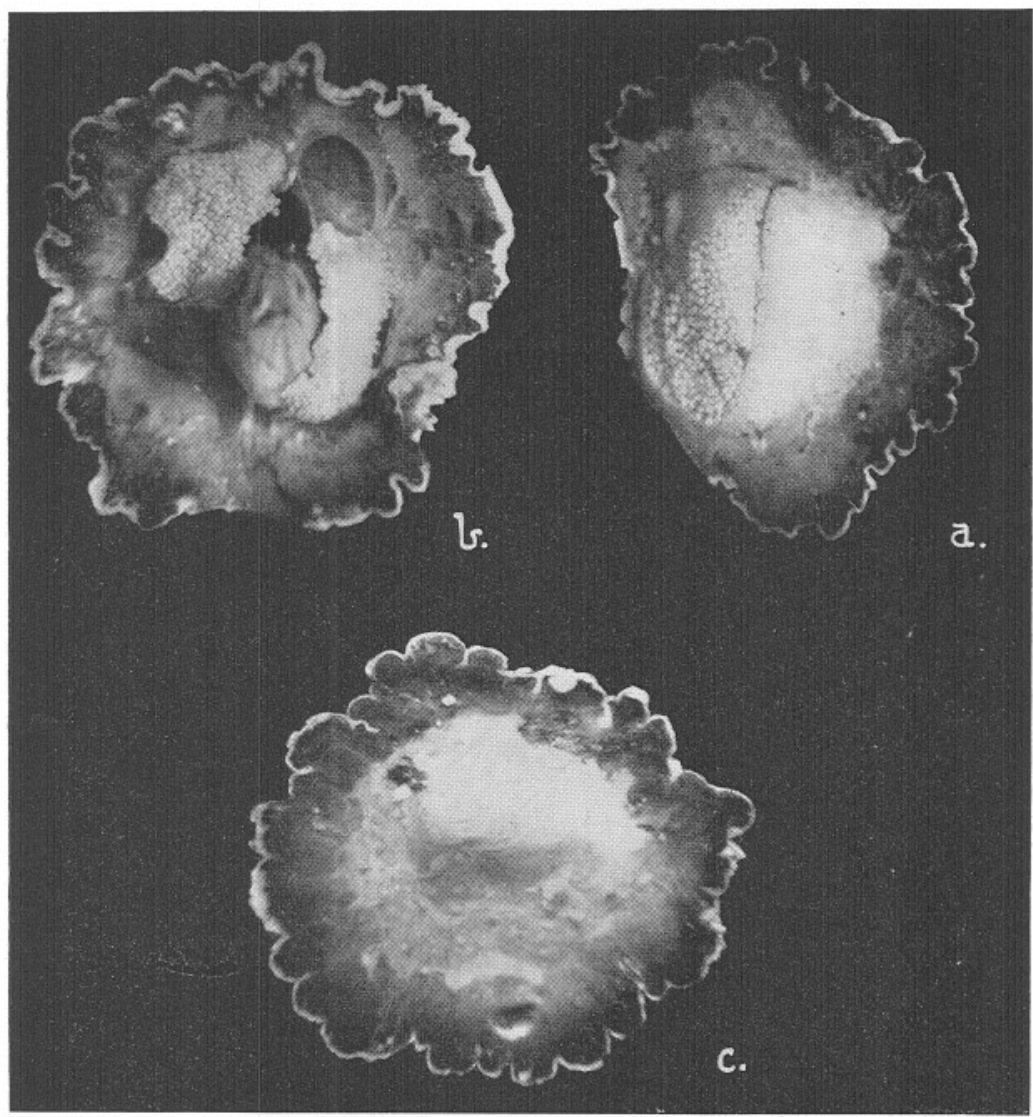

Fig. 2.-B. balanoides from the top zone at Port Erin, seen from below. (a) A normal individual with full complement of nauplii in the mantle cavity. (b) Early condition of senility with reduced number of nauplii. (c) Advanced stage of senility with no nauplii, and swollen, fatty ovary. $\times 4$.

whole or a part of each was counted on a ruled slide. The results obtained are given in Table VI, and in Figure 3 are shown the superimposed outlines of the scatters for the three levels.

At the lowest level (B.1) breeding takes place a year earlier than at either of the other two levels, and this, together with the smaller growthrate at B.1, allows larvæ to be found in much smaller specimens there 
than elsewhere. Otherwise the three levels are similar except for the larger barnacles on B.3. Here, owing to the appearance of senile individuals among the larger barnacles, the lower limits of the scatter drop to zero above a size of about $100 \mathrm{~mm}^{3}$. The upper limits on all three levels are similar. As an example of the wide range of naupliar content found in the larger specimens on B.3, four specimens with sizes of $209,210,211$ and $216 \mathrm{~mm}^{3}$. respectively had naupliar contents of 0,5890 , 13110 and 2043.

Figure 4 shows the larval output of average individuals of successive

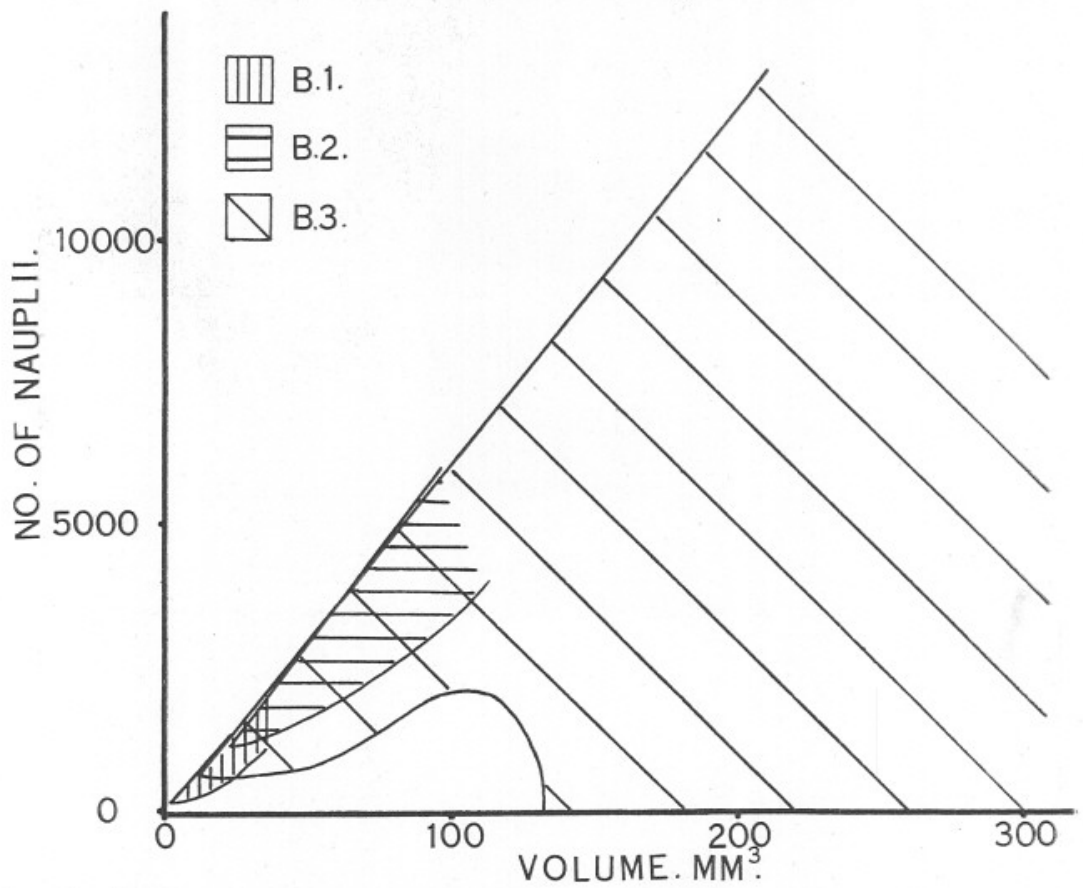

FIG. 3.-Relation of naupliar content to size in B. balanoides at Port Erin at low-level (B.1), intermediate- (B.2) and high-level (B.3).

year groups at the three levels, calculated from the growth stages previously obtained for that locality (Moore, 1934). The low level, B.1 barnacles, by reason of their earlier spawning, yield, from the point of view of the plankton, a quicker return than do those from higher levels, but their size in their first year is so small that their larval output is almost negligible, and few of them survive to spawn a second time. In their first spawning year the output of B.2 and B.3 is very similar, lying between 1500 and 2000 larvæ per individual, but in subsequent years the proportion of senile non-spawning individuals on B.3 reduces the average output on B.3 slightly below that for barnacles of the same age on B.2, 
despite the slightly greater size of the former. On the other hand very few B.2 barnacles survive to spawn more than twice, whereas the B.3 type may apparently live and spawn for a number of years.

In order to obtain an estimate of the weight of a nauplius, a number of barnacles were taken from the shore in March, 1934, just prior to the time of spawning. After removal from the rocks the barnacles were stirred up in sea-water and the larvæ set free. These were then decanted into one end of a long glass vessel which was illuminated only from the other

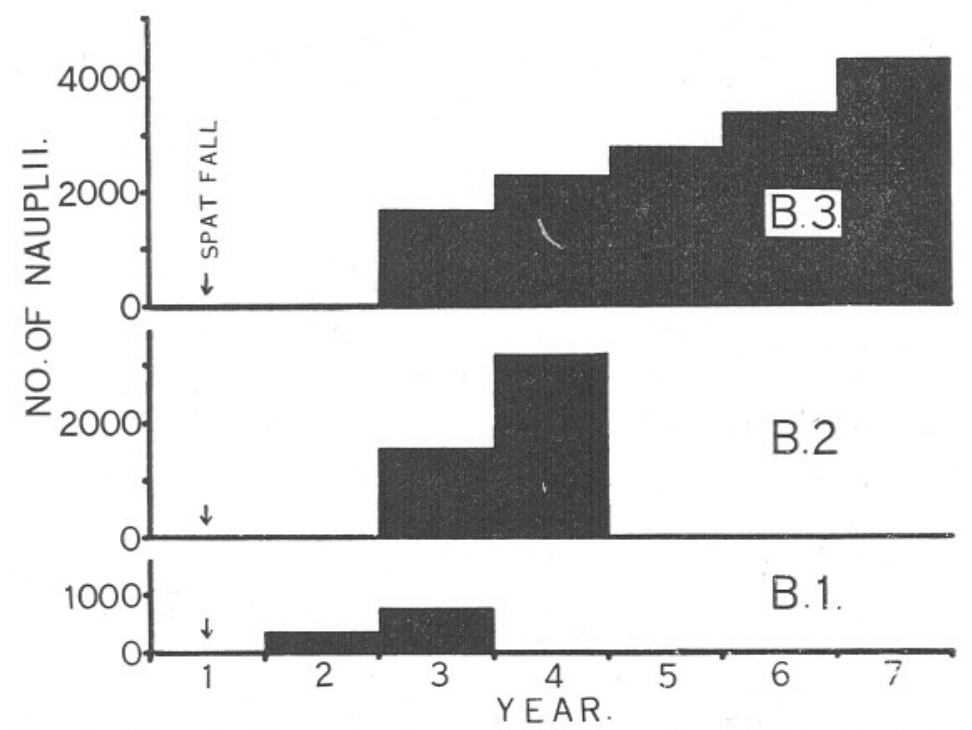

Fig. 4.-Mean naupliar output in successive years at three levels at Port Erin.

end. The liberated larvæ swam towards the light, so that a pure suspension of them could be siphoned off from that end of the vessel. The number of larvæ so obtained was estimated as 3,480,000 from a series of counts of aliquot portions. The larvæ were then collected on a weighed filter paper, washed by drawing a small quantity of distilled water over them, and dried to a constant weight in a boiling-water oven. From these the average weight of one nauplius was estimated as $7 \cdot 5 \times 10^{-4} \mathrm{mgm}$.

\section{SUMMARY.}

1. The relation between the dry weight of the decalcified barnacle and its shell volume has been determined in its relation to age, season and tidal level, at Port Erin, with the following results : (a) In immature barnacles, tissue growth continues throughout the year, but is most rapid in the spring and autumn. (b) In mature barnacles which produce a considerable 
amount of larvæ there is a heavy drop in tissue weight during the summer period of high temperature, and another slighter drop during the winter, the latter being apparently associated with the presence of developing larvæ in the mantle cavity.

2. Gonad samples were examined seasonally. At low levels on the shore the barnacles mature in their first year. Above this level they do not commence to mature until over a year old. The sequence of changes in the gonads is described. A condition of senility is found in many of the largest high-water barnacles.

3. The naupliar content was estimated in relation to size and tidal level, counts of up to 13,000 larvæ per individual being obtained. The dry weight of a fully developed nauplius was determined to be $7 \cdot 5 \times 10^{-4} \mathrm{mgm}$.

\section{REFERENCES.}

Darwin, C. 1851. A Monograph of the Sub-Class Cirripedia. London, Ray Soc.

Elmhirst, R. E. 1922. Notes on the Breeding and Growth of Marine Animals in the Clyde Sea Area. Ann. Rept. Scot. Mar. Biol. Assoc. for 1922 .

Grave, B. H. 1933. Rate of Growth, Age at Sexual Maturity and Duration of Life of certain sessile Organisms at Woods Hole, Massachusetts. Biol. Bull., Vol. LXV, No. 3 .

Hatton, H., and Fischer-Piette, E. 1932. Observations et Expériences sur le Peuplement des Côtes rocheuses par les Cirripèdes. Bull. de l'Inst. océanog. Monaco., No. 592.

Hoєk, P. P. C. 1876. Zur Entwicklungsgechichte der Entomostraken. I. Embriologie von Balanus. Niederländlisches Arch. f. Zool. Bd. III.

Johnstone, J., Sсотт, A., and Сhadwick, H. C. 1924. The Marine Plankton. Liverpool, The University Press Ltd.

Kaмm, M. W. 1922. Studies on Gregarines. II. Synopsis of the polycystid Gregarines of the world, excluding those from the Myriapoda, Orthoptera and Coleoptera. Ill. Biol. Monogr., Vol. VII.

KrüGer, P. L. 1927. Tierweldt der Nord- und Ost See. X. d., Cirripedia.

Lebour, M. V. 1911. A Review of the British Marine Cercariæ. Parasitology, Vol. 4.

Moore, H. B. 1934. The Biology of Balanus balanoides. I. Growth Rate and its Relation to Size, Season and Tidal Level. Journ. Mar. Biol. Assoc., N.S., Vol. XIX, No. 2. 
Orton, J. H. 1933. Studies on the Relation between Organism and Environment. Trans. Liverpool Biol. Assoc., Vol. XLVI, for 1932.

Parke, M. W., and Moore, H. B. 1935. The Biology of Balanus balanoides. II. Algal Infection of the Shell. Journ. Mar. Biol. Assoc., N.S., Vol. XX, No. 1.

Runnström, S. 1925. Zur Biologie und Entwicklung von Balanus balanoides (Linné). Bergens Mus. Aarbok., 1924-1925, 1 Hefte, Nr. 5, Naturv. Raekke.

Spence-Bate, C. 1868. Impregnation of the Balani. Ann. and Mag. Nat. Hist., Ser. IV, Vol. III.

Trégouboff, G. 1912. Sur les Grégarines des Balanes. Arch. Zool. exp. et gén., Ser. 5, Vol. X.

\section{TABLE I.}

Observed Mean Tissue Weights and Mean Shell Volumes on August 2.̆тh, 1932, at Port Erin.

Weights in mgm.; volumes in $\mathrm{mm}^{3}$. (see p. 263).

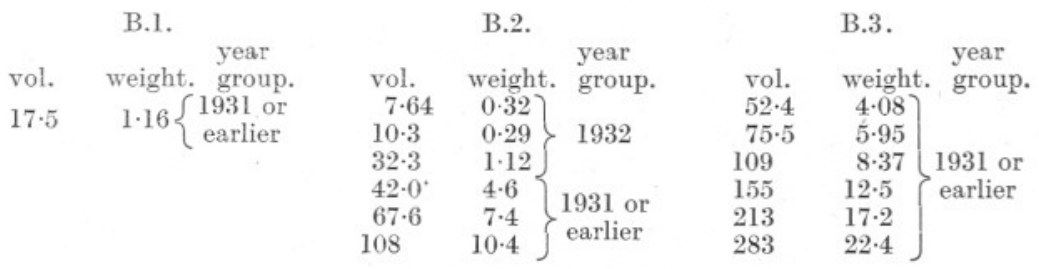

TABLE II.

Observed Mean Tissue Weights and Mean Shell Volumes on October 25th, 1932, at Port Erin.

Weights in mgm.; volumes in $\mathrm{mm}^{3}$.

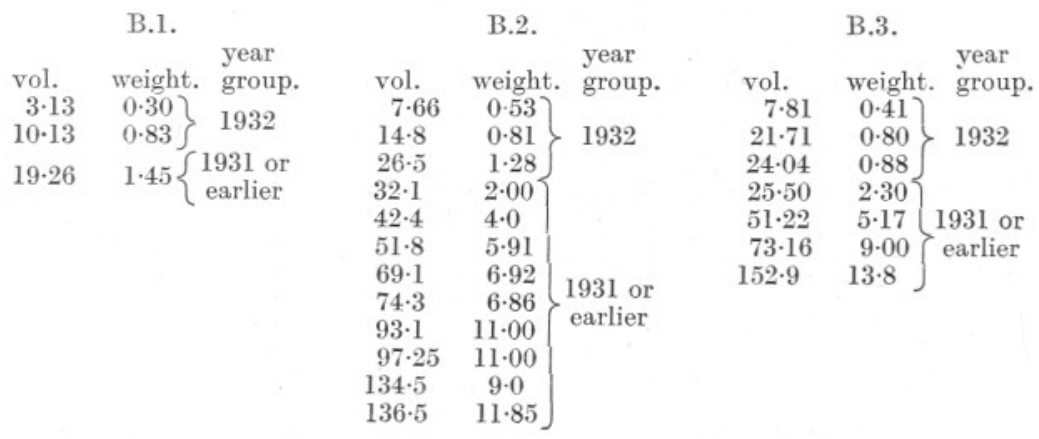




\section{TABLE III.}

\section{Observed Mean Tissue Weights and Mean Shell Volumes on January 25th, 1933, at Port Erin.}

Weights in mgm.; volumes in $\mathrm{mm}^{3}$.

B.1.

year

vol. weight. group.

$\begin{array}{lll}3.63 & 0 \cdot 29 & 1932\end{array}$

$\left.\begin{array}{ll}5 \cdot 38 & 0 \cdot 61 \\ 9 \cdot 16 & 0 \cdot 88\end{array}\right\} 1931$ or

$14 \cdot 4$

$30 \cdot 6$

\section{B.2.}

vol. $4 \cdot 95$

$10 \cdot 8$

$20 \cdot 3$

$25 \cdot 6$

$28 \cdot 6$

$56 \cdot 8$

$76 \cdot 3$

$89 \cdot 8$ $\begin{array}{ll}\text { weight. } & \text { group }\end{array}$

$0 \cdot 407$

$0 \cdot 92\} 1932$

$0.81\} 1932$

$1 \cdot 39$

$2 \cdot 25$

$4 \cdot 00 \backslash 1931$ or

$5 \cdot 80$ earlier $7 \cdot 30$
B.3.

vol. weight. year

$10 \cdot 1-0.46$

$20 \cdot 7 \quad 1 \cdot 10\} \quad 1932$

$30 \cdot 1 \quad 1 \cdot 38$

$33 \cdot 1 \quad 2 \cdot 96$

$68.2 \quad 5 \cdot 22 \quad 1931$ or

$104 \quad 8.42\}$ earlier

$23 \cdot 4$

\section{TABLE IV.}

Observed Mean Tissue Weights and Mean Shell Volumes on April 26th, 1933, at Port Erin.

Weights in mgm.; volumes in $\mathrm{mm}^{3}$.

B.1.

$\begin{array}{ccc}\text { vol. } & \text { weight. } & \begin{array}{c}\text { year } \\ \text { group }\end{array} \\ \left.\begin{array}{cc}15.97 & 1.48 \\ 28.7 & 2.92 \\ 4.35\end{array}\right\} & \text { ? }\end{array}$
B.2.

vol. weight. group.

$8 \cdot 15 \quad 0.83$

$14 \cdot 3 \quad 1 \cdot 32 \quad 1939$

$24 \cdot 9 \quad 2 \cdot 23\} 1932$

$29 \cdot 8 \quad 3 \cdot 00\}$

$74 \cdot 0 \quad 5 \cdot 64\{1931$ or

$94 \cdot 2 \quad 7 \cdot 86\}$ earlier
B.3.

year vol. weight. group. $\begin{array}{ll}7 \cdot 68 & 1.28 \\ 17 \cdot 4 \cdot 3 & 1.82\end{array}$

$17 \cdot 4 \quad 1.82\} 1932$

$33.4 \quad 3.46$

$67 \cdot 9 \quad 4 \cdot 33\{1931$ or

$\left.\begin{array}{c}94 \cdot 3 \\ 16 \cdot 5\end{array}\right\}$ earlier

\section{TABLE V.}

Observed Mean Tissue Weights and Mean Shell Volumes on JUNE 14TH, 1933.

Weights in mgm.; volumes in $\mathrm{mm}^{3}$.

B.1.

$\begin{array}{ccc} & & \text { year } \\ \text { vol. } & \text { weight. } & \text { group. } \\ 1 \cdot 75 & 0 \cdot 17 & 1933 \\ 9 \cdot 85 & 2 \cdot 25 & 1932 \text { or } \\ 20 \cdot 3 & 3 \cdot 73 & \text { earlier }\end{array}$

B.2.

year

$\begin{array}{ccc}\text { vol. } & \text { weight. } & \text { group. } \\ 0 \cdot 77 & 0 \cdot 068 & 1933\end{array}$

$0 \cdot 7$

$19 \cdot 7$

$35 \cdot 7$

$50 \cdot 1$

$96 \cdot 6$
$2 \cdot 127$

$3 \cdot 72(1932$ or

$4 \cdot 82\}$ earlier

8.00 earlier

$\left.\begin{array}{ccl} & \text { B.3. } & \\ \text { vol. } & \text { weight. } & \begin{array}{l}\text { year } \\ \text { group. }\end{array} \\ 0 \cdot 75 & 0 \cdot 070 & 1933 \\ 25 \cdot 2 & 2 \cdot 45 \\ 41 \cdot 3 & 3 \cdot 26 & \\ 45 \cdot 2 & 3 \cdot 45 & \\ 48 \cdot 2 & 5 \cdot 26 & \\ 52 \cdot 0 & 6 \cdot 12 & \\ 105 & 8 \cdot 06 \\ 158 & 11 \cdot 2 & \\ 268 & 19 \cdot 8\end{array}\right\}$




\section{TABLE VI.}

Individual Naupliar Contents of Balanus balanoides at Port Erin, February, 1933.

\begin{tabular}{|c|c|c|c|c|c|c|c|}
\hline \multicolumn{2}{|c|}{ B.1. } & \multicolumn{2}{|c|}{ B.2. } & \multicolumn{2}{|c|}{ B.3. } & \multicolumn{2}{|c|}{ B.3. } \\
\hline $\begin{array}{l}\text { Vol. } \\
\mathrm{mm}^{3} \text {. }\end{array}$ & $\begin{array}{l}\text { No. of } \\
\text { Nauplii. }\end{array}$ & $\begin{array}{c}\text { Vol. } \\
\text { in } \mathrm{mm}^{3} \text {. }\end{array}$ & $\begin{array}{l}\text { No. of } \\
\text { Nauplii. }\end{array}$ & $\begin{array}{c}\text { Vol. } \\
\text { in } \mathrm{mm}^{3} \text {. }\end{array}$ & $\begin{array}{l}\text { No. of } \\
\text { Nauplii. }\end{array}$ & $\begin{array}{c}\text { Vol. } \\
\text { in } \mathrm{mm}^{3} \text {. }\end{array}$ & $\begin{array}{l}\text { No. of } \\
\text { Nauplii. }\end{array}$ \\
\hline $3 \cdot 52$ & 218 & $24 \cdot 9$ & 1160 & $29 \cdot 7$ & 757 & 163 & 3970 \\
\hline $4 \cdot 62$ & 226 & $31 \cdot 0$ & 1190 & $38 \cdot 5$ & 662 & 177 & 8438 \\
\hline $6 \cdot 22$ & 251 & $34 \cdot 8$ & 1240 & $43 \cdot 6$ & 843 & 195 & none \\
\hline $6 \cdot 68$ & 173 & $46 \cdot 8$ & 2290 & $46 \cdot 0$ & 2230 & 195 & 3020 \\
\hline $6 \cdot 68$ & 174 & $59 \cdot 6$ & 1830 & $49 \cdot 7$ & 2930 & 205 & 7030 \\
\hline $7 \cdot 47$ & 173 & $64 \cdot 5$ & 2760 & 56.5 & 1250 & 209 & 9460 \\
\hline $8 \cdot 74$ & 419 & $66 \cdot 8$ & 3440 & $68 \cdot 0$ & 2460 & 209 & none \\
\hline $9 \cdot 28$ & 173 & $67 \cdot 0$ & 4040 & $68 \cdot 8$ & 2230 & 210 & 5890 \\
\hline $9 \cdot 86$ & 413 & $67 \cdot 6$ & 2230 & $77 \cdot 1$ & 3433 & 211 & 13110 \\
\hline $10 \cdot 5$ & 420 & $72 \cdot 2$ & 2200 & $77 \cdot 4$ & 1710 & 216 & 2043 \\
\hline $11 \cdot 8$ & 431 & $72 \cdot 5$ & 4400 & $86 \cdot 0$ & 2250 & 217 & 5327 \\
\hline $12 \cdot 5$ & 532 & $85 \cdot 9$ & 2610 & $93 \cdot 0$ & 2190 & 232 & 9590 \\
\hline $12 \cdot 5$ & 386 & 101 & 5210 & $93 \cdot 1$ & 2350 & 234 & 5020 \\
\hline $12 \cdot 5$ & 328 & 102 & 6070 & $97 \cdot 4$ & 3700 & 235 & none \\
\hline $13 \cdot 9$ & 507 & 110 & 4230 & 122 & 5140 & 241 & 4210 \\
\hline $13 \cdot 9$ & 611 & 112 & 5600 & 131 & none & 243 & none \\
\hline $15 \cdot 5$ & 280 & 113 & 3980 & 135 & none & 250 & 7360 \\
\hline $15 \cdot 5$ & 401 & 115 & 5850 & 141 & 5480 & 254 & 10770 \\
\hline $16 \cdot 4$ & 404 & & & 161 & 4770 & 266 & 6090 \\
\hline $18 \cdot 1$ & 543 & & & 163 & none & 301 & 6466 \\
\hline $18 \cdot 1$ & 725 & & & & & & \\
\hline $24 \cdot 1$ & 1372 & & & & & & \\
\hline $25 \cdot 2$ & 623 & & & & & & \\
\hline $35 \cdot 4$ & 1162 & & & & & & \\
\hline $39 \cdot 8$ & 1022 & & & & & & \\
\hline
\end{tabular}


